\title{
Consumption of Tea in Professionals and Non-professionals
}

\author{
Safila Naveed* and Asra Hameed \\ Department of Pharmacy, Jinnah University for Women, Karachi, Pakistan
}

Received: August 07, 2014, Accepted: September 03, 2014, Published: September 16, 2014

*Corresponding author: Safila Naveed, Department of Pharmacy, Jinnah University for Women, Karachi-74600, Pakistan; E-mail: safila117@yahoo. com

\begin{abstract}
Tea is an important part of our daily life and culture. People consume it for refreshment especially during breakfast or after breakfast. It tastes good and is the cheapest drink consumed worldwide. It contains fluoride which is very helpful in our physiological and some of the pathological conditions. It also contains caffeine, which is a CNS stimulant and causes addiction of it. Now it has become a need for its users due to its addiction. Our study aimed to find out its consumption and its addiction in different age groups and genders belonging to different professions. A cross-sectional method was used to collect data from different universities, offices and other public places in Karachi city.

According to our survey tea consumption is prevalent among all age groups. 2-3 cups of tea is the mostly consumed amount of tea. People (around 49\%) mostly consume 2-3cups of tea daily. The consumption of tea is more prevalent in males than in females. It causes addiction so the common symptoms found in people were headache and sedation. Tea consumption in the professional class is greater as compared to the non-professionals. While some other consume tea but they are not addicted of it. According to our survey $17 \%$ people had never consumed tea.
\end{abstract}

Keywords: Tea; Caffeine; CNS stimulant; Addiction; Professionals; Non-professionals

\section{Introduction}

Tea is the agricultural product of the leaf buds, leaves, and internodes of many cultivars and sub-varieties of the Camellia sinensis plant, and is processed and cured using various methods [1]. The aromatic beverage prepared from the cured leaves by combination with hot or boiling water, is also referred to as tea. Tea is the common name for the Camellia sinensis plant itself [2]. Tea, is the world's most favored beverage; as it is a generally acceptable drink, with lots of benefits, and is comparatively cheaper than other beverages. After water, it is the second most drunk beverage in the world. Its plant originated from South East China and slowly spread to India, Pakistan and other countries [3]. Tea contains fluoride which prevents dental decay. It also prevents the deposition of cholesterol on the artery wall, which in turn can help avoid heart disease. Tea is also useful in combating bacterial diseases of the intestines because it has been found to con- tain compounds which prevent multiplication of bacteria. Tea is also useful in the control of diseases caused by radiation [3]. Tea drinking is a long tradition in Pakistan which has now become, an integral part of our social life. Pakistan is the third largest importer of tea after England and Russia, and the consumption of tea in the country is increasing day by day with the increase in population [4]. On an average each Pakistani, consumes a kilo of tea, each year.Kenya has $55 \%$ shares in the market so it is the largest exporter of black tea to Pakistan [5]. Pakistan has a market of 170 million kg for black tea, which, it imports from 21different countries of the world including Kenya, India, Indonesia, Sri Lanka \& Bangladesh. International quality regulation only approved Black tea [6].

A type of antioxidant, Catechin is found in tea [7]. Theanine and the stimulant caffeine at about $3 \%$ of its dry weight is found in the tea, translating to between $30-90 \mathrm{mg}$ per $8 \mathrm{oz}(250 \mathrm{ml} /$ cup)depending on type, brand and brewing method $[8,9]$. Tea also contains small amounts of Theobromine and Theophylline [10]. Fluoride and aluminum have also been found to occur in tea, due to modern day environmental pollution with certain types of brick tea made from old leaves and stems having the high levels $[11,12]$.

Caffeine is an addictive drug and overuse of tea may result in harmful adverse effects, like increased likelihood of certain sleep disorders [13].

\section{Methodology}

A cross-sectional survey was conducted for the collection of data about the common tea consumption practice in professionals and non-professionals in Karachi. Data were collected between April to June, 2014 from different public places, offices, schools, and hospitals in Karachi city. A specially designed questionnaire was used for data collection. Data from 50 professionals and 50 non-professionals were collected. Different questions were asked from the professionals and non-professionals belonging to different age groups and genders like how much tea (in cups) they consumed each day? Why they take tea? How they feel if they don't take tea? The questionnaire was designed in order to check the daily consumptions and addiction of tea in non-professional people and people belonging to different professions. 


\section{Data Analysis}

We have used pie charts and graphical representation for the statistical analysis of data obtained.

\section{Results}

According to our survey, 17\% people belonging to different age groups and different professions do not consume tea. Other people consume tea in different frequencies. Our analysis also revealed that male consume more tea than females. We analyzed that tea caused addiction in many users so they experience headache and sedation, if they don't take tea. We also analyzed that professionals (males and females) consume more tea than that of non-professionals.

\section{Discussion}

Tea is a cheap beverage, and is commonly consumed all around the world. We surveyed 100 people, to check tea consumption across different age groups, genders, and professions. It is also consumed as a part of breakfast, in Pakistani culture. People also drink tea, as they enjoy its good taste.

People who are addicted to tea feel symptoms like sedation, headache, tiredness, fatigue, drowsiness etc, if they don't take tea. Some people are not addicted to tea and they use it very less, so they may even feel relaxed without consuming tea. Tea is used in people of different age groups belonging to different professions. In the age group of 18-25 years, 69 people were questioned about their tea intake habit; 14 people in this age group do not drink tea, whereas 12 people drink only a cup of tea, daily.

The study reflected that in this age group, 33 people drink 2-3 cups of tea, 9 people take 4-5 cups of tea, whereas one person has more than 8 cups of tea, daily.

In the age group of 26-33 years, 15 people answered the questionnaire; out of which 3 people do not consume tea, 1 person consumes only one cup of tea, 8 people drink 2-3 cups of tea, and 3 people consume $4-5$ cups of tea, daily.
Total 5 people answered the questionnaire in the age group of 34-41 years; out of which 2 people consume only one cup tea, 2 people drink 2-3 cups, and one person consumes 4-5 cups of tea, per day. In the next age group, which is $42-49$ years; 2 people were questioned, and they both consume 2-3 cups of tea daily. Out of the 6 people that were questioned in the age group of 50-57 years; 2 people drink 1 cup, 3 people have 2-3 cups and only one person has 4-5 cups of tea, daily. In our survey 3 people belonged to the age group of 58-65 years; out of which 1 has 2-3 cups and 2 people have 4-5 cups of tea, per day.

In our survey 100 people were asked question about their tea drinking habit, 42 males and 58 females were asked about their habits. According to our survey, 4 males and 13 females answered that they do not consume tea. Whereas, 4 males and 13 females answered that they take only a single cup of tea per day; 26 males and 23 females answered that they consume 2-3 cups of tea daily and 7 males and 9 females drink 4-5 cups of tea every day. Only one male answered that he drinks 8 cups or more tea daily. We have analyzed that males consume more tea than that of females.

Due to high amount of caffeine in tea, it causes addiction to its users. According to our survey $41 \%$ feel normal if they don't take tea that means they are not addicted to tea. In these 41 peoples, 17 people never consumed tea while 10 consume only a single cup of tea, 10 people drink 2-3 cups, and 4 people drink 4-5 cups daily. 36\% people feel headache if they don't have tea, which means they are extreme addicted to tea. In these 36 peoples, 4 consume 1 cup, 26 consume 2-3 cups, 5 consume 4-5 cups and one consume more than 8 cups of tea daily. $7 \%$ people feel sedation if they don't take tea that also proved its addiction, in which 2 people drink 1 cup, 4 people drink 2-3 cups, and only 1 person takes 4-5 cups of tea daily. Other symptoms like tiredness, drowsiness, fatigue, depression, anxiety, body pain, etc. are experienced by $16 \%$ people according to our survey. Even some people answered that they can't live without tea. Results are given in Tables 1-5 and Figures 1-4.

Data was collected from 50 professionals and 50 non-

Table 1: Consumption of tea in different age group.

\begin{tabular}{|c|c|c|c|c|c|c|c|}
\hline & & \multicolumn{5}{|c|}{ Consumption of Tea } & \multirow[b]{2}{*}{ Tota } \\
\hline & & $\begin{array}{c}\text { Non- } \\
\text { consumers }\end{array}$ & 1cup & $2-3$ cups & 4-5 cups & 8 or more cups & \\
\hline \multirow{6}{*}{ Age groups } & $18-25$ years & 14 & 12 & 33 & 9 & 1 & 69 \\
\hline & 26-33 years & 3 & 1 & 8 & 3 & 0 & 15 \\
\hline & 34-41years & 0 & 2 & 2 & 1 & 0 & 5 \\
\hline & $42-49$ years & 0 & 0 & 2 & 0 & 0 & 2 \\
\hline & 50-57 years & 0 & $2 \mathrm{v}$ & 3 & 1 & 0 & 6 \\
\hline & 58-65 years & 0 & 0 & 1 & 2 & 0 & 3 \\
\hline \multicolumn{2}{|c|}{ Total } & 17 & 17 & 49 & 16 & 1 & 100 \\
\hline
\end{tabular}

Table 2: Consumption of tea in different gender.

\begin{tabular}{|c|c|c|c|c|c|c|c|}
\hline \multirow{2}{*}{\multicolumn{2}{|c|}{ 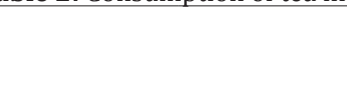 }} & \multicolumn{5}{|c|}{ Consumption of Tea } & \multirow{2}{*}{ Total } \\
\hline & & Non-consumers & 1 cup & $2-3$ cups & 4-5 cups & 8 or more cups & \\
\hline \multirow{2}{*}{ Gender } & Male & 4 & 4 & 26 & 7 & 1 & 42 \\
\hline & Female & 13 & 13 & 23 & 9 & 0 & 58 \\
\hline \multicolumn{2}{|c|}{ Total } & 17 & 17 & 49 & 16 & 1 & 100 \\
\hline
\end{tabular}


Table 3: Symptoms of tea addiction.

\begin{tabular}{|c|c|c|c|c|c|c|}
\hline Symptoms & $\begin{array}{c}\text { Non- } \\
\text { consumers }\end{array}$ & $\mathbf{1 c u p}$ & $\begin{array}{c}\mathbf{2 - 3} \\
\text { cups }\end{array}$ & $\begin{array}{c}\mathbf{4 - 5} \\
\text { cups }\end{array}$ & $\begin{array}{c}\mathbf{8} \text { or } \\
\text { more } \\
\text { cups }\end{array}$ & Total \\
\hline Normal & 17 & 10 & 10 & 4 & 0 & 41 \\
\hline Headache & 0 & 4 & 26 & 5 & 1 & 36 \\
\hline Sedation & 0 & 2 & 4 & 1 & 0 & 7 \\
\hline $\begin{array}{c}\text { Other } \\
\text { symptoms }\end{array}$ & 0 & 1 & 9 & 6 & 0 & 16 \\
\hline Total & 17 & 17 & 49 & 16 & 1 & 100 \\
\hline
\end{tabular}

Table 4: Consumption of tea in professional and non professional.

\begin{tabular}{|c|c|c|c|c|c|c|}
\hline & $\begin{array}{c}\text { Non- } \\
\text { consumers }\end{array}$ & $\mathbf{1 c u p}$ & $\begin{array}{c}\mathbf{2 - 3} \\
\text { cups }\end{array}$ & $\begin{array}{c}\mathbf{4 - 5} \\
\text { cups }\end{array}$ & $\begin{array}{c}\mathbf{8} \text { or } \\
\text { more } \\
\text { cups }\end{array}$ & Total \\
\hline Professionals & 1 & 3 & 31 & 14 & 1 & 50 \\
\hline $\begin{array}{c}\text { Non } \\
\text { Professionals }\end{array}$ & 16 & 14 & 18 & 2 & 0 & 50 \\
\hline Total & 17 & 17 & 49 & 16 & 1 & 100 \\
\hline
\end{tabular}

Table 5: Chi-Square Test.

\begin{tabular}{|c|c|c|c|}
\hline Pearson Chi-Square & Value & df & $\begin{array}{c}\text { Asymp. } \\
\text { Sig. } \\
\text { (2-sided) }\end{array}$ \\
\hline $\begin{array}{c}\text { Consumption of tea in different age } \\
\text { group }\end{array}$ & 15.068 & 20 & 0.772 \\
\hline $\begin{array}{c}\text { Consumption of tea in different } \\
\text { gender }\end{array}$ & 8.624 & 4 & 0.071 \\
\hline Symptoms when tea is not consumed & 44.962 & 12 & 0 \\
\hline $\begin{array}{c}\text { Consumption of tea in professional } \\
\text { and non professional }\end{array}$ & 33.802 & 4 & 0 \\
\hline
\end{tabular}

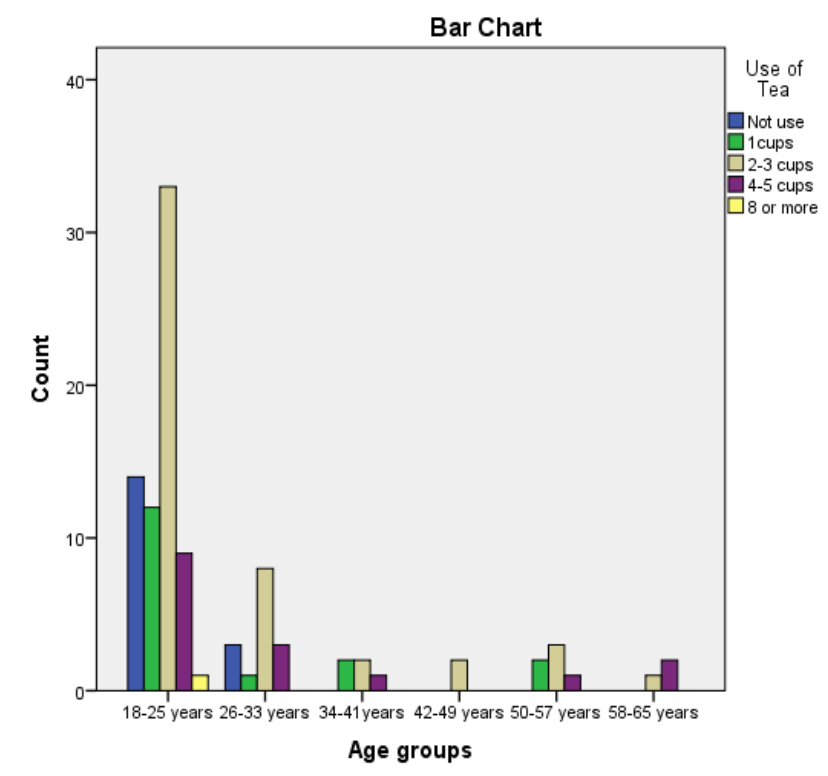

Figure 1: Consumption of tea in different age group.

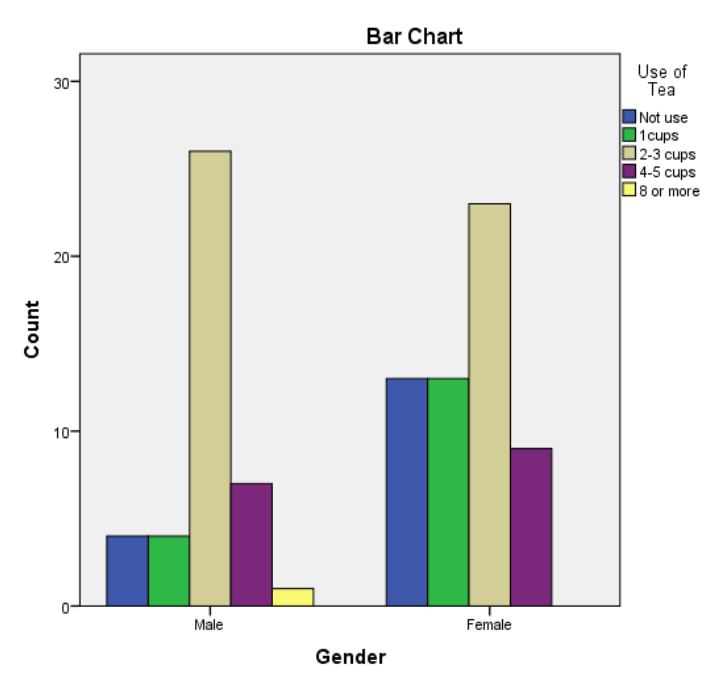

Figure 2: Consumption of tea in different gender.

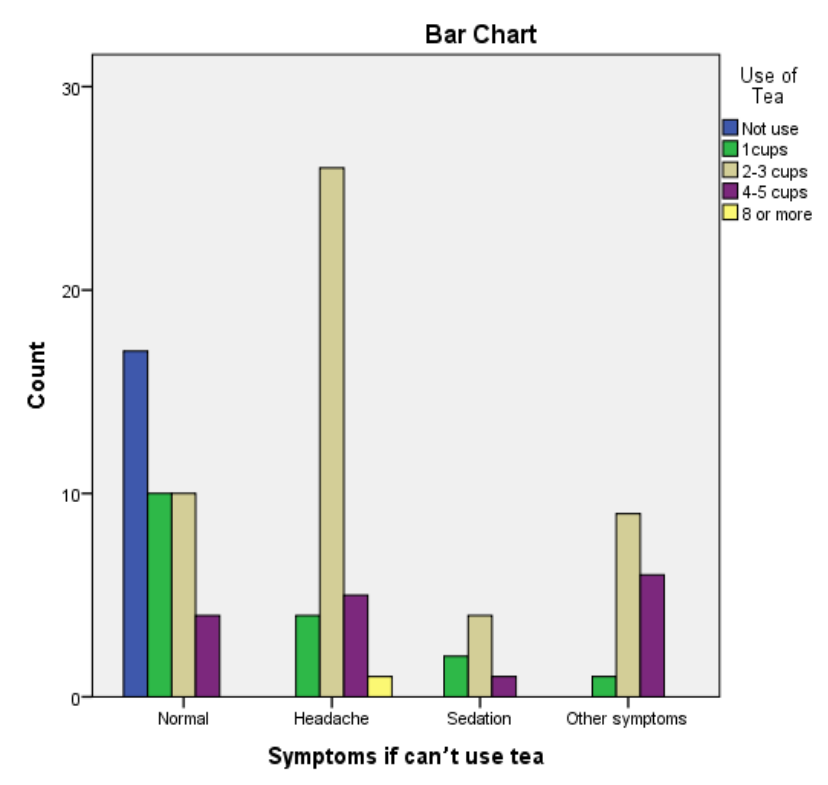

Figure 3: Symptoms when not use tea.

professionals to check their daily consumption of tea. The survey revealed that $17 \%$ people never take tea, in which 16 are nonprofessionals and only 1 is professional. Also, 17\% use 1 cup tea, in which 14 were non-professionals and 3 were professionals. $49 \%$ people answered that they take $2-3$ cups of tea daily, out of which, 18 were non-professionals and 31 were professionals. $16 \%$ people drink 4-5 cups of tea, in which 14 are professionals and only 2 were non-professionals. Among the total number of people who were surveyed, only one person (a professional) consumed 8 or more cups of tea, daily.

\section{Conclusion}

After the survey we have concluded that the use of tea is very common in our society, especially in people belonging to 


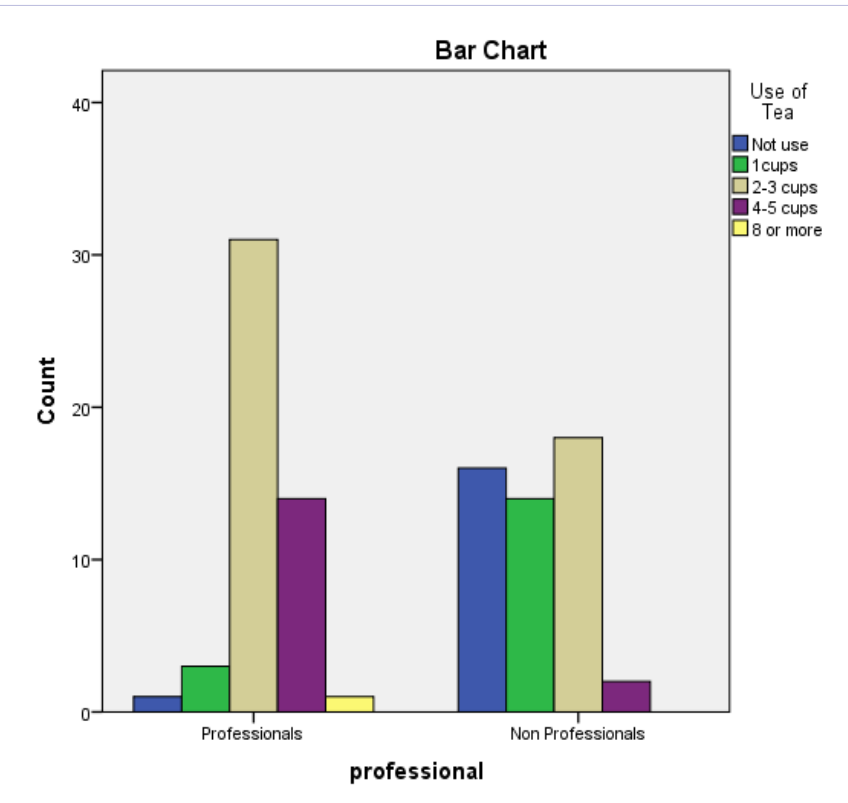

Figure 4: Consumption of tea in professional and non professional.

different professions and has become a need and part of our daily life. People use it for refreshment. Headache and sedation are common symptoms of its addiction. Tea use is more common in males than females. Professionals are more likely to take tea than of non-professionals.

\section{Acknowledgement}

We would like to thank the management of offices, universities and different public places for their support.

\section{References}

1. Tea Guardian. Quality Basics 1: Various Plants, Various Qualities. [Cited 2010 Dec 22]; Available from: http:/ / teaguardian. com/ nature of_tea/ nature_of_teal. html.

2. In: Philip Babcock Gove, editor. Webster's Third New International
Dictionary of the English Language, Unabridged. Massachusetts: MerriamWebster, Inc; 2002.

3. Noor Ahmed Memon. Exclusive on Tea, Tea: A Common Man's Drink. Pakistan Food Journal. 2013.

4. Shamsul Islam, Qamar-uz-Zaman, Sohail Aslam, Fayaz Ahmad, Sajjad Hussain, FS Hamid. EFFECT OF FOLIAR SPRAY OF VARYING NITROGEN LEVELS ON MATURE TEA YIELD UNDER DIFFERENT AGROECOLOGICAL CONDITIONS. J Agric Res. 2012; 50(4):1-8.

5. Central Asia Online. Growth of tea consumption is good news for Pakistan's importers and... smugglers [Internet]. Amna Nasir Jamal, editor. [2009 Sep 11]. Available from: http://centralasiaonline.com/ en_GB/articles/caii/features/2009/09/11/feature-03.

6. Dominic Medley. THE GROWING MEDIA LANDSCAPE IN AFGHANISTAN. The RUSI Journal. 2010; 155(1):30-35. doi: $10.1080 / 03071841003683401$.

7. wondersoftea.com [Internet]. [cited 2009 Jul 02]. Available from: http://www.wondersoftea.com/posts/health/which-tea-is-healthiest.html.

8. Bennett Alan Weinberg, Bonnie K. Bealer. The World of Caffeine: The Science and Culture of the World's Most Popular Drug. UK: Routledge; 2004.

9. Monique B Hicks, YH P Hsieh, Leonard N Bell. Tea preparation and its influence on methylxanthine concentration. Food Research International. 1996; 29(3-4):325-330.

10. Graham HN. Green tea composition, consumption, and polyphenol chemistry. Preventive Medicine. 1992; 21(3):334-50.

11. MW Ho. Institute of Science in Society [Internet]. London: Mae-Wan Ho. 2007 Jan- [cited 2011 Jan 24]. Available from: http://www.i-sis.org. uk/Fluoride_in_Tea.php.

12. Fung KF, Zhang ZQ, Wong JWC, Wong MH. Fluoride contents in tea and soil from tea plantations and the release of fluoride into tea liquor during infusion. Environmental Pollution. 1998; 104(1999):197-205.

13. Bhagwat S, Beecher GR, Haytowitz DB, Holden JM, Dwyer J, Peterson J, et al. Flavonoid composition of tea: Comparison of black and green teas. USDA Agricultural Research Service. Available from: http:/ / www. nal. usda. gov/ fnic/ foodcomp/ Data/Other/ IFT2003_TeaFlav. pdf. 